\title{
Patronage lies at the heart of Italy's academic problems
}

\section{Funds are distributed through a system that runs on}

Sir - Would the single key priority of transparent and modernized selection rules for directors of new Italian National Research Council (CNR) institutes identified in your Opinion article "A stain on Italian reforms" (Nature 414, 133; 2001) provide a sufficient turning point for the current poor system? In Italy, there is a heavy tradition of centralized, 'top down' authority in the distribution of funding that has little to do with the quality of research.

Since 1995, owing to the apparent bankruptcy of our institute, we have been supported financially in our research only by organizations that have appreciated our work and reputation, and not by the CNR. The heart of the matter is a lack of healthy competitiveness for research funds in our country. A first step for change could be giving administrative and academic autonomy to individuals who are highly motivated and sufficiently skilled to do excellent research.

As you state in your article, funding at present is assigned through academic heads who sit on the commissions and share out the available posts and other resources on the basis of personal connections rather than on merit. In this context, the challenge is to ensure a clear chain of responsibility from top to bottom and therefore to radically improve the research skills of the entire workforce of the CNR. This remedy is urgently needed.

Sad to say, academic promotion within the CNR is still based on recommendations and favours: a degrading spectacle including 'vote exchange' at all levels of promotion. This policy discourages innovation, as there is no clear career structure based on academic merit and results. If individuals with initiative and talent could at last enjoy their just rewards, the necessary profound renewal of the entire system might begin to happen.

As things stand, those without friends in high places remain barred from academic promotion, irrespective of their competence, and it can take four to five years to evaluate a candidate for promotion within the CNR. Claudio Chiesa, Lucia Pacifico Institute of Neurobiology and Molecular Medicine, National Research Council, c/o Institute of Pediatrics, "La Sapienza" University of Rome, Viale Regina Elena 324, 00161-Rome, Italy

\section{CNR choices were made on the basis of capability}

Sir - Your editorial "A stain on Italian reforms" (Nature 414, 133; 2001) seems inspired by prejudice about some specific appointments made by the Italian National Research Council (CNR), rather than by the wish to understand the real basis of the decisions.

It is not true, as your article states, that the final decision on the appointment of institute directors is taken by the president. In fact, a board is in charge of each appointment; each member of the board votes for one of the candidates on a shortlist drawn up by a commission of peers on the basis of scientific achievement and managerial experience. The majority vote (where the president's vote counts for one) determines the choice.

In choosing new directors, the board has always taken into account the ability of the candidate to manage the transition from the old structure to the new one, which requires skills in reduction and consolidation of the institutes as well as integration between different projects. Hence, our preferred candidates have excellent managerial experience and other personal characteristics, as well as distinguished scientific rank.

Finally, I fail to understand your statement that some choices derived from trading votes for favours among the members of the board. The great majority of the decisions were taken by consensus. Lucio Bianco, President

CNR, Piazzale Aldo Moro, 7-00185 Rome, Italy

\section{A challenge for research in Italy: to raise the dead}

Sir — The dead body of Italian research was buried well before last month's mock funeral in Milan, reported in your News story "Funding fears spark Italian protest" (Nature 414, 384; 2001). There is little to sob about in limiting the expansion of the
National Research Council (CNR) and of other public Italian research institutions that produce so little. One should, instead, complain about the Mafia-like rules afflicting Italian public institutions and determining the aberrant selection of candidates that will be such a negative influence on Italian science for years to come.

The recent failure to appoint highprofile scientists for several CNR institute directorships simply confirms what the vast majority of exiled Italian scientists have learned the hard way: nothing is really changing in the Italian science system. Therefore, it would have been wiser for Italian scientists working in public institutions to use their wit to change the rules. Public funding should be used to try to resuscitate the dead, not to refurbish the funeral parlour. Arturo Sala

Molecular Haematology and Cancer Biology Unit, Institute of Child Health, 30 Guilford Street, London WC1N 1EH, UK

\section{Open debate is essential on conservation issues}

Sir - In their peevish review of Bjørn Lomborg's book The Skeptical Environmentalist (Nature 414, 149-50; 2001), Stuart Pimm and Jeff Harvey miss the main point just as they have in their comments in the same review on Julian Simon's 1996 book The Ultimate Resource. The main target of both books is the politicization of ecology that has created a dogmatic environmentalism.

In their rush to rubbish Lomborg's book, the reviewers perhaps missed the significance of Lomborg's title. What Lomborg, and Simon before him, describe is the continued disparity between apocalyptic claims for the future of mankind, with figures issued from large organizations such as the United Nations Food and Agriculture Organization, which often or even usually show the opposite.

Pimm and Harvey state that there are ecological laws that ensure the correctness of doom-laden predictions. Presumably one of these laws enabled the environmentalist Paul Ehrlich to state in his 1968 book The Population Bomb: "The battle to feed all of humanity is over. In the 1970s and 80 s, hundreds of millions of people will starve to death."

Laws do not exist in biology, only generalizations; there are exceptions to every biological principle. Extrapolating from the past to predict a doom-andgloom future has been an industry from Malthus onwards. But the ultimate resource is the creativity and skill of the 
human intellect; formulating the problem often generates solutions.

Democracy needs some people to shout loudly about the problems of the world in which we live, but such claims must be treated critically. That is Lomborg's thesis. Pimm and Harvey tell us that the main extinction threat is to species nothing is known about, which suggests these claims are hand-waving exercises. If nothing is known, how can extinction - or even teetering on the brink be predicted?

If wilderness and species are to be saved from extinction, farming should be as efficient as possible. Excess agricultural land can then be returned to its original condition. Conservation is important, of course, but Pimm and Harvey's review suggests a common confusion with preservation. Human survival is the priority. Like all species in large numbers, our presence drives others to extinction. But new species will evolve to take advantage of the new environments created.

Open democratic debate about conservation policy is essential because there are many calls on public resources. The policies that are decided have to be the best return for money, and the public should vote on the outcome. In listing with glee the industry that will attempt to rubbish, instead of debate, Lomborg's book, Pimm and Harvey may have shot themselves in their feet. Such vehemence invites the conclusion that Lomborg (and Simon) have indeed exposed basic flaws in green political dogma.

Anthony Trewavas

Institute of Cell and Molecular Biology, Mayfield Road, University of Edinburgh, Edinburgh EH9 3JH, Scotland

\section{Belief in our dominion is a backward step}

Sir - It is disheartening to read your News item "Vatican approves use of animal transplants 'to benefit humans"' (Nature 413, 445; 2001). It is the rationale of the Pontifical Academy, rather than its approval of xenotransplantation, that is particularly worrisome.

According to your report, "the academy argues that because humans enjoy a unique and superior dignity, and God has placed non-human creatures at the service of people, the sacrifice of animals is justified as long as there will be a 'relevant benefit for humans."'

This smacks of a return to predarwinian human arrogance and egotism. Didn't humanity long ago abdicate its monarchy over creation, giving up at last the notion of 'special creation' and human 'dominion over all things'? Even in the thirteenth century, St Francis of Assisi preached that all of nature, having been created by God, is important and worthy of respect.

I can think of few more dangerous attitudes than that promulgated in Genesis 1:28 and now by the Vatican, exhorting humanity, as the crown of creation, to "have dominion ... over every living thing". At what cost, mastery?

\section{Robert C. Fleck}

Physical Sciences Department, Embry-Riddle Aeronautical University, 600 S. Clyde Morris Blvd, Daytona Beach, Florida 32114, USA

\section{It's Sulston all right - but not as we know him}

Sir-Martin Kemp, in his "Science in Culture” article on Mark Quinn's A Genomic Portrait: Sir John Sulston points out that rather than a portrait, the artist has generated something akin to a relic (Nature 413, 778; 2001).

In the artist's production of an artefact which may not be art, there is more than a hint of a parallel with Sulston's achievement. Here the scientist (and the Human Genome Project) has generated something which is not science, but a remarkable triumph of technology and organization - a catalogue of the human genome sequence. The interpretation of this triumph awaits the ingenuity of contemporary and future scientists.

Quinn has enlisted collaborators too; several million bacteria, some of which have been persuaded to take up fragments of Sulston's DNA. Like most representations, aspects of the subject will be missing from the finished work unclonable portions of DNA which have not inserted into the bacteria. Artists consciously or unconsciously choose to emphasize certain features and downplay or omit others. In Quinn's case, he cannot direct the omission and lacks the means to decode the image for the observer.

Jerry Lanchbury

Molecular Immunogenetics Unit, Department of Rheumatology, Division of Medicine, GKT School of Medicine, King's College, London SE1 9RT, UK

\section{Reality hits postdocs earlier in France}

Sir - Your News story "Young, gifted ... and spurned" on the French postdoctoral system (Nature 414, 145; 2001) portrays a one-sided view of the French system. Although your report makes some valid points, it fails to acknowledge that the UK and US systems have many disadvantages, in the light of which it is not clear that the French system is worse.

In France, scientists gain tenure much earlier than their counterparts in Britain and the United States, which means that the former have more time and opportunity to formulate long-term research plans. Not every piece of research can generate several papers a year. Many topics, such as child development or ecology, need to be followed for years before a conclusion can be reached.

British and US postdocs generally waste a lot of potential research time writing proposals for renewal of short-term contracts. In the French system, postdocs are civil servants, so are less susceptible to having their research directed and can more easily conduct 'unfashionable' research without fear of losing next year's support.

The temporary contracts used in the UK and US systems mean that people can be forced to do 'trendy' research, or the research that one's professor or head of department wants done, to safeguard funding. This is not conducive to originality - it takes time to tell whether a piece of research is of fundamental importance. Bibliometric measures only tell us which topics are popular, but we could all be wrong, as history has often shown.

The deluge of postdoctoral workers in British and US universities stems from the often indiscriminate recruitment of $\mathrm{PhD}$ students essentially to do technicians' work but more cheaply and more disposably. Hence, after obtaining a $\mathrm{PhD}$ and holding a postdoctoral post or two, it becomes difficult to continue, because a disproportionately large number of qualified candidates are chasing a smaller number of vacancies. In France, it is difficult to find a job immediately after obtaining a $\mathrm{PhD}$. So the difference between the two systems is that reality hits the researcher earlier in France.

There are more postdocs for each tenured post in the British system than in the French system. Even if there were not, it could be argued that the French system is fairer, as researchers know early on in their career if they can continue in scientific research, and are likely to be able to change careers more effectively than they can when they are older.

P.-L. Chau

Department of Biochemistry, University of Cambridge, Cambridge CB2 1QW, UK

\section{correspondence}

contributions to correspondence may be submitted to corres@nature.com. They should be no longer than 500 words, ideally shorter. Published contributions are edited for length. 